\title{
UPAYA PENINGKATAN PEMAHAMAN KONSEP KOGNITIF DALAM PEMBELAJARAN FISIKA MENGGUNAKAN MODEL PEMBELAJARAN POE (PREDICT-OBSERVE-EXPLAIN) BERBASIS INKUIRI
}

\author{
Nisa Siti Rahmadona \\ FKIP Pendidikan Fisika \\ Universitas Siliwangi Tasikmalaya, \\ Jawa Barat, Indonesia \\ Email: nsrahmadona2@gmail.com
}

\begin{abstract}
The purpose of this paper: 1. To understand cognitive concepts, 2. Application of the learning model POE (Predict-Observe-Explain), 3. Explain the inquiry model. The learning process that occurs so far has not yet optimally developed students' thinking abilities. One learning model that involves students' role actively while still raising the characteristics of science is that students are able to develop the knowledge they possess by scientific proof is to use the POE (Predict-Obiserve-Explain) learning model which is expected to improve understanding of cognitive concepts in physics learning. The POE model provides opportunities for students to produce their own conceptual knowledge through reconciliation and negotiation between initial knowledge and new knowledge. And to find out the interaction of learning models with the understanding of physics concepts.
\end{abstract}

Keywords: POE, understanding cognitive concepts, inquiry models.

ABSTRAK: Tujuan penulisan ini : 1. Untuk memahami konsep kognitif, 2. Penerapan model pembelajaran POE (Predict-Observe-Explain), 3. Menjelaskan model inkuiri. Proses pembelajaran yang terjadi selama ini belum secara optimal mengembangkan kemampuan berpikir siswa. Salah satu model pembelajaran yang melibatkan peran siswa secara aktif dengan tetap memunculkan karakteristik IPA yaitu siswa mampu mengembangkan pengetahuan yang dimilikinya dengan pembuktian secara ilmiah adalah dengan menggunakan model pembelajaran POE (Predict-Obiserve-Explain) yang diharapkan dapat meningkatkan pemahaman konsep kognitif dalam pembelajaran fisika. Model POE memberikan kesempatan bagi siswa untuk menghasilkan pengetahuan konseptual mereka sendiri melalui rekonsiliasi dan negosiasi antara pengetahuan awal dan pengetahuan baru. Dan untuk mengetahui interaksi model pembelajaran terhadap pemahaman konsep fisika.

Kata kunci: POE, pemahaman konsep kognitif, model inkuiri. 


\section{PENDAHULUAN}

Proses pembelajaran yang terjadi selama ini belum secara optimal mengembangkan kemampuan berpikir siswa. Pelaksanaan proses pembelajaran yang berlangsung di kelas diarahkan untuk peserta didik menghafal informasi dan latihan soal-soal yang disampaikan. Peserta didik dilatih untuk mengingat dan menimbun berbagai informasi tanpa dituntut untuk mencerna dan memahami makna yang terkandung didalamnya dan tidak dihubungkan dengan kehidupan seharihari apalagi untuk menemukan atau menyelidiki suatu konsep, dengan demikian pembelajaran yang dilakukan masih belum dapat melibatkan peserta didik dalam mengembangkan kemampuannya untuk memahami konsep. Oleh karena itu diperlukan suatu proses pembelajaran yang dapat membuat siswa memahami konsep-konsep IPA dengan baik. Salah satu model pembelajaran yang melibatkan peran siswa secara aktif dengan tetap memunculkan karakteristik IPA yaitu siswa mampu mengembangkan pengetahuan yang dimilikinya dengan pembuktian secara ilmiah adalah dengan menggunakan model pembelajaran POE (Predict-Observe-Explain) yang diharapkan dapat meingkatkan pemahaman konsep. Seperti menurut Teerasong et all. menyatakan, model POE memberikan kesempatan bagi siswa untuk menghasilkan pengetahuan konseptual mereka sendiri melalui rekonsiliasi dan negosiasi antara pengetahuan awal dan pengetahuan baru. (Izza Aliyatul Muna, 2017).

Kurikulum merupakan perangkat yang sangat penting karena menjadi dasar dari proses pendidikan. Kurikulum menjadi muara dari seluruh kegiatan pembelajaran. Kurikulum merupakan kunci utama untuk mencapai sukses dalam dunia pendidikan. Kurikulum harus selalu diubah secara periodik untuk disesuaikan dengan kebutuhan pengguna. Pemerintah Indonesia melalui Departemen Pendidikan dan Kebudayaan menerapkan kebijakan pendidikan dari Kurikulum Tingkat Satuan Pendidikan (KTSP) menjadi Kurikulum 2013. Diharapkan kurikulum 2013 dapat menghasilkan insan indonesia yang produktif, kreatif, inovatif, afektif melalui penguatan sikap, keterampilan, dan pengetahuan yang terintegrasi (Kemdikbud, 2013a, hal 77).

Kurikulum 2013 menuntut pembelajaran Fisika di SMA dilaksanakan secara saintifik untuk menumbuhkan kemampuan berpikir, bekerja, dan bersikap ilmiah serta berkomunikasi sebagai salah satu aspek penting kecakapan hidup. Pembelajaran pada kurikulum 2013 berbasis saintifik dengan lima langkah pembelajaran (5M) yang meliputi mengamati (observasing), menanya (questioning), menalar (Associating), mencoba (experimenting), dan membentuk Jaringan (Networking). Sesuai dengan tujuan Kurikulum 2013 Madrasah Aliyah (MA) atau Sekolah Menengah Atas (SMA), tujuan belajar bukan hanya menguasai informasi yang diberikan oleh guru, melainkan juga mengembangkan sikap yang positif terhadap belajar, penelitian, dan penemuan serta pemecahan masalah atas kemampuan sendiri dengan pendekatan langkahlangkah saintifik, dimana langkah-langkah kegiatan ini dirancang untuk pembelajaran yang sedemikian rupa agar perserta didik seara aktif mengonstruk konsep, hukum atau prinsip melalui tahapan 5M yang meliputi (5M) yang meliputi mengamati (observasing), menanya (questioning), menalar (Associating), mencoba (experimenting), dan membentuk Jaringan (Networking). Fisika juga merupakan suatu proses penemuan. Mata pelajaran Fisika menjelaskan seluruh fenomena yang terjadi di alam ini, sehingga masalah-masalah yang berhubungan dengan Fisika kerap kita jumpai dalam kehidupan sehari-hari. Dengan demikian peranan pembelajaran Fisika adalah melatih para 
peserta didik untuk dapat menguasai pengetahuan, konsep dan prinsip Fisika, memiliki kecakapan ilmiah dan memiliki keterampilan proses sains. Dalam perkembangan proses belajar, seorang guru berperan sebagai fasilitator. Peran ini memberi kesempatan bagi guru untuk semaksimal mungkin memfasilitasi kebutuhan para muridnya. Mengiringi peran guru sebagai fasilitator berbagai inovasi media pembelajaran dilakukan. Penggunaan media sebagai pendamping dalam proses pembelajaran semakin dibutuhkan untuk mengatasi permasalahan yang muncul karena keterbatasan waktu, tempat, dan fasilitas lainnya.

\section{METODE PENELITIAN}

Metode yang digunakan dalam penulisan ini berupa studi kepustakaan. Data dikumpulkan untuk dianalisis kemudian disajikan dalam hasil dan pembahsan agar dapat dibuat kesimpulan.

\section{HASIL DAN PEMBAHASAN}

\section{Model POE (Predict-Obiserve-Explain)}

Menurut (Izza Aliyatul Muna, 2017) Model pembelajaran POE (Predict-Oiserve-Explain) adalah model pembelajaran yang diperkenalkan oleh White dan Gustone. Menurut White \& Gunstone dalam Wu-Tsai, POE dikembangkan untuk menemukan kemampuan memprediksi siswa dan alasan mereka dalam membuat prediksi tersebut mengenai gejala sesuatu yang bertujuan untuk mengungkap kemampuan siswa dalam melakukan prediksi. White dan Gunstone, menyatakan bahwa POE sebagai model yang efektif untuk memperoleh dan meningkatkan konsep sains peserta didik. Hasil penelitian juga menunjukan bahwa kegiatan POE dapat digunakan oleh guru untuk merancang kegiatan belajar yang dimulai dengan sudut pandang siswa.

Pembelajaran dengan Model POE ini menggunakan 3 langkah utama, yaitu:

1. Prediction (prediksi)

Prediksi suatu proses membuat dugaan terhadap suatu peristiwa. Dalam membuat dugaan, siswa akan diminta guru memberikan alasan dari dugaannya, yaitu mengapa ia memilih prediksi tersebut. Pada proses ini siswa diberikan kebebasan seluas-luasanya untuk menyusun dugaan dengan alasannya, guru tidak membatasi pemikiran siswa sehingga banyak gagasan dan konsep muncul dari pemikiran siswa, karena semakin banyak dugaan yang muncul dari pemikiran siswa, guru akan dapat mengerti bagaimana konsep dan pemikiran siswa tentang persoalan yang diajukan (ibid dalam Izza Aliyatul Muna, 2017). Hal ini penting bagi guru dalam membantu siswa untuk membangun konsep yang benar. Jadi dalam tahap model POE yaitu memprediksi siswa akan dijak memprediksi yaitu memberi dugaan dari suatu demonstrasi yang diberikan guru, harapannya siswa akan mengalami konflik kognitif pada tahap ini.

2. Observation (observasi atau pengamatan)

Observasi merupakan keterampilan ilmiah yang mendasar. Siswa dalam melakukan observasi menggunakan semua indra. Tahap ini siswa diajak untuk melakukan percobaan atau eksperimen, tujuannya yaitu untuk menguji kebenaran prediksi yang mereka sampaikan. Siswa mengamati apa yang terjadi, yang terpenting dalam langkah ini adalah 
konfirmasi atas prediksi mereka. Tahap pertama setelah konflik kognitif terjadi, tahap selanjutnya yaitu membuktikan dugaannya dengan melakukan suatu eksperimen. Dengan melakukan eksperimen diharapkan akan ada proses ketidakseimbangan antara konsep yang baru dihayati dengan yang dibawa dari luar (dibangun atas dasar akal sehat). Mereka mengadakan pengulangan pegamatan, membuat pengukuran, menganalisis, menafsirkan data yang selanjutnya berakhir dengan menarik kesimpulan (Ibid dalam Izza Aliyatul Muna, 2017).

\section{Explanation (explanasi)}

Eksplanasi yaitu pemberian penjelasan terutama tentang kesesuaian antara dugaan dengan hasil eksperimen pada tahap observasi. Apabila hasil prediksi tersebut sesuai dengan hasil observasi dan setelah mereka memperoleh penjelasan tentang kebenaran prediksinya, maka siswa semakin yakin akan konsepnya. Akan tetapi, jika dugaannya tidak tepat maka siswa dapat mencari penjelasan tentang ketidaktepatan prediksinya. Siswa akan mengalami perubahan konsep dari konsep yang tidak benar menjadi benar. Disini, siswa dapat belajar dari kesalahan, dan biasanya belajar dari kesalahan tidak akan mudah dilupakan. Menurut Kunia Novita Sari (dalam Izza Aliyatul Muna, 2017) Hal-hal yang perlu diperhatikan dalam model pembelajaran POE adalah sebagai berikut: a. Masalah yang diajukan sebaiknya masalah yang memungkinkan terjadi konflik kognitif dan memicu rasa ingin tahu. b. Prediksi harus disertai alasan yang rasional. Prediksi bukan sekedar menebak. c. Demonstrasi harus bisa diamati dengan jelas, dan dapat memberi jawaban atas masalah. d. Siswa dilibatkan dalam proses eksplanasi.

\section{Pemahaman konsep kognitif}

Kemampuan pemahaman konsep kognitif untuk menunjang kemampuan belajar siswa dengan cara matematis diperlukan pembelajaran yang bermakna, dimana peserta didik dituntut untuk tidak pasif dan tidak berhenti pada materi yang disajikan oleh guru, tetapi sebagai subyek yang aktif melakukan proses berfikir, mencari, mengolah, mengurangi, menggabung, menyimpulkan, dan menyelesaikan masalah. Berdasarkan teori epistemologi empiris menekankan akan kebutuhan lingkungan belajar dengan menyediakan kesempatan siswa belajar untuk mengembangkan dan membangun pengetahuan melalui pengalamannya. Oleh karena itu, lingkungan berpengaruh terhadap proses pembelajaran salah satunya adalah gaya kognitif. Gaya kognitif merupakan perbedaan cara seseorang dalam memproses informasi (Eunjoo \& Doohun, 2005). Gaya kognitif merupakan suatu cara yang dilakukakan oleh peserta didik memersepsikan dan mengorganisasikan informasi dari sekitarnya (berkaitan dengan cara merasakan, mengingat, memikirkan, memecahkan masalah, dan membuat kesimpulan).

\section{Model inkuiri}

(Nana,dkk, 2017)Model pembelajaran Inquiry merupakan cara pembelajaran yang mengajarkan kepada siswa untuk menjadi kfitis, analisis argumentatif dalam mencari jawabanjawaban berbagai permasalahan yang ada di alam, melalui pengalamanpengalaman dan sumber lainnya. Pada dasarnya inquiry adalah sautu perluasan proses discovery (penemuan) dalam cara 
yang lebih dewasa, sebagai tambahan pada proses discovery, Inquiry mengandung proses-proses mental yang lebih tinggi tingkatannya. Dalam pelaksanaannya model Inquiry itu menghadapkan siswa kepada situasi bertanya-tanya (Gulo, 2008) Pembelajaran inquiry dirancang untuk mengajak siswa secara langsung ke dalam proses ilmiah dalam waktu yang singkat. Hasil penelitian Schlenker, dalam Joyce dan Well (2009), menunjukkan bahwa latihan inquiry dapat meningkatkan pemahaman sains, produktif dalam berikir kreatif, dan siswa menjadi terampil dalam memperoleh informasi.

Model pembelajaran inquiry ini cocok diterapkan dalam pembelajaran Fisika. Hal ini dikarenakan Model inquiry lebih menekankan pada keaktifan siswa dalam belajar, siswa terlebih dahulu mengadakan. kegiatan-kegiatan di laboratorium atau disekitar yaitu proses mengamati, mencatat hasil pengamatan, menganalisis dan menyimpulkan kegiatan praktikum yang dirancang oleh guru. Hal itu akan membtiat belajar Fisika menjadi lebih menyenangkan dan lebih berkesan, karena siswa terlibat langsung dalam proses pembelajaran, Fisika merupakan mata pelajaran yang bukan menuntut hafalan namun perlu dimengerti, dipahami dan diterapkan. Dengan model pembelajaran inquiry diharapkan dapat memudahkan siswa dalam memahami konsep Fisika dan dapat merangsang kemampuan berkomunikasi ilmiah siswa sehingga terbentuk suatu interaksi antara siswa dan guru dan pembelajaran menjadi lebih bermakna.

Inkuiri dalam bahasa Inggris disebut sebagai Inquiry berarti pertanyaan atau pemeriksaan, penyelidikan. Gulo (2008) mengatakan model pembelajaran inkuiri berarti suatu rangkaian kegiatan belajar yang melibatkan secara maksimal seluruh kemampuan siswa untuk mencari dan menyelidiki secara sjstematis, kritis, logis, analitis, sehingga mereka dapat merumuskan sendiri penemuannya dengan penuh percaya diri. Dalam bukunya Gulo juga menyebutkan sasaran utama daii kegiatan pembelajran ikuiri yakni: 1). Keterlibatan siswa secara maksimal dalam proses kegiatan belajar, 2) keterarahan kegiatan secara logis dan sistematis pada tujuan pembelajaran, dan 3) mengembangkan sikap percaya pada diri siswa tentang apa yang ditemukan dalam proses inkuiri (2008) Model Inquiry bisa disebut juga model "penemuan" merupakan model pembelajaran relative baru yang diperkenalkan kepada guru. Sumatri dan Permana mengatakan bahwa model penemuan adalah cara penyajian pelajaran yang memberi kesempatan kepada peserta didik untuk menemukan informasi dengan atau tanpa bantua guru. (2001). Model pembelajaran ini melibatkan peserta didik dalam proses mental untuk menemukan sendiri konsep yang diajarkan. Dengan menggunakan proses pembelajaran inkuiri yang berlangsung ini pada siswa diberi kesempatan untuk aktif dalam pembelajaran baik dengan mental, intelektual, dan sosial emosional. Dan pada pembelajaran langsung lebih menekankan tanpa diberikan waktu untuk merefleksikan materi yang diterima. dalam pembelajaran inkuiri ini dilatih agar siswa dapat memecahkan masalah, meningkatkan pemahaman konsep kognitif terhadap fisika. 


\section{PENUTUP}

Dari berbagai permasalahan yang telah dijabarkan dapat ditarik kesimpulan dan dimaknai bahwa model pembelajaran POE ini dapat meningkatkan proses pembelajaran siswa, sehingga dapat meningkatkan hasil belajar siswa, karena dalam prosesnya melibatkan siswa yaitu dengan metode diskusi sehingga siswa lebih semangat untuk mengikuti pelajaran yang diterima. Dengan adanya model ini pembelajaran lebih bermakna. Tetapi model ini memliki kekurangan yaitu memerlukan alat-alat penunjang dalam pembelajaran fisika sehingga cocok digunakan disekolah yang memiliki peralatan fisika (praktikum) yang lengkap dan guru yang kreatif.

\section{UCAPAN TERIMAKASIH}

Terima kasih kepada semua pihak yang telah membantu demi kesempurnaan artikel ini menjadi lebih baik, diantaranya:

1. Kepada Bapak Dr. Nana, M.Pd. selaku dosen pengampu mata kuliah Fisika Sekolah II;

2. Kepada Teman-teman yang telah membantu menyelesaikan jurnal ini.

\section{DAFTAR PUSTAKA}

Depdiknas. (2008). Penulisan Modul. Jakarta: Direktorat Jenderal PMPTK, Depdiknas.

Izza Aliyatul Muna. (2017). Model pembelajaran POE (predict-observe-explain) dalam meningkatkan pemahaman konsep dan keterampilan proses IPA. Institut Agama Islam Negeri ponorogo. 5(1). [Tersedia] file://C:/Users/Asus/Downloads/3028-Article\%20Text8083-1-10-20170814.pdf

Nana,dkk. (2017). Upaya Peningkatan Kemampuan Kognitif dan Komunikasi Ilmiah Siswa Kelas $\mathrm{X}$ MIA 1 SMA Negeri 1 Ciamis Menggunakan Model Pembelajaran Inquiry. [Tersedia] http://jurnal.unsil.ac.id/index.php/Diffraction/article/view/812/529

Yunieka Putri Sukiminiandari,dkk. (2015). Pengembangan modul pembelajaran fisika dengan pendekatan saintifik. Volume 5. [Tersedia] file:///C:/Users/Asus/Downloads/5000Article\%20Text-8638-1-10-20171209.pdf 